\title{
The philosophical problems in modern fiction: The concept of being in E. Schmitt's "Noah's child"
}

\author{
Elena Ivanova ${ }^{1, *}$, Ekaterina Ivanova ${ }^{2}$ \\ ${ }^{1}$ Orsk Institute for Humanities and Technology (branch of Orenburg State University), Orsk, 644105, \\ Russia \\ ${ }^{2}$ RUDN University, Moscow, 117198, Russia
}

\begin{abstract}
The article is devoted to the analysis of the novel by a contemporary writer, E.E. Schmitt "Noah's child" in terms of the realization of the important philosophical problems, updated with the time. The novelty of the given material is due primarily to the choice of the author, whose work is still to be reflected. This article examines the philosophical issues of existence implemented at various levels of the literary text: from the title to its symbolism. Drawing on biblical and historical material, in a novelistic genre E. Schmitt managed to present his vision of the problems of faith and disbelief, identity of the nation, the moral choice, etc. While not denying the value of the God in human perception of the world, the writer asserts the idea that the man himself is responsible for all what is happening on the ground and in the society, so the novel "Noah's child" can be seen as a passionate appeal to contemporaries to strive for the harmony of coexistence.
\end{abstract}

\section{Introduction}

The inextricable internal connection of literary creativity with philosophy is due to the desire of both thinkers and writers to learn the secrets of being. Philosophers move towards this goal with the help of logical analysis, through the creation of a certain system of knowledge, ideas about the world and man. Writers, comprehending the laws of being, transmit their vision of the world by artistic means. Based on the ideas of philosophers and masters of the artistic word create a more vivid and emotional picture of being. However, the various ways in which thinkers and writers move toward revealing the secrets of being do not share, but, on the contrary, combine philosophy and literature. "A philosopher," wrote V.G. Belinsky, - "says syllogisms, the poet expresses himself with images and pictures, and they both talk about the same thing. The political economist, armed with statistical numbers, proves, acting on the minds of his readers or listeners, that the position of a certain class in society has improved much or worsened due to such reasons. The poet, armed with a lively and vivid depiction of reality, shows, in a true picture, acting on the imagination of his readers that the position of such class in society has really improved or

\footnotetext{
*Corresponding author: iva17051@yandex.ru
} 
worsened from such reasons. One proves, the other shows, and both convince, only one with logical arguments, the other with images ... Here science and art are equally necessary, and neither science can replace art, nor the art can replace science" (Belinskij, 1956, p. 225). Belinsky's ideas related to the tasks and specific features of art were largely tested and confirmed by time.

Fiction, like any art in general, is a form of reproduction of reality. At the same time, literature reflects the hero's attitude to this reality, appeals to the best spiritual qualities, affects the reader's feelings, urging him to follow high spiritual ideals to make the world a better place. This manifests the "educational" potential of literature, which philosophy does not have. Aristotle spoke of this particular feature of literature, emphasizing it by comparing literature with history: "The historian and the poet differ from each other not only in that one uses the dimensions, but the other does not, it would be possible to transfer Herodotus' works to poetry, they would be history with or without a meter; but they differ in that the first speaks of what really happened, and the second speaks of what could happen. Therefore, poetry is more philosophical and serious than history: poetry speaks of the general, history speaks of the particular" (Aristotel, 1957, p. 186).

It should be noted that the symbiosis of literature and philosophy is a phenomenon with a rather rich history, which is reflected in the vast art material, beginning with the ancient Greek tragedies of Aeschylus, Sophocles, Euripides and ending with the authors of modern bestsellers. Each era actualized its philosophical problems dictated by reality. That is why the works of Dante, F. Rabelais, Voltaire with their capacious philosophical problems are perceived by the modern reader remotely, in the format of historical and cultural fact, since the ideas that worried the authors do not meet the demands of our time. Large-scale political events significantly affected the philosophical content of fiction: the Great French Revolution, the Napoleonic Wars, the First World War, the October Revolution in Russia, the Second World War, etc. They identified new vectors in the philosophical assimilation of reality and provided a wealth of material for creating literary works, in which precisely these events gave rise to serious philosophical reflections. We can take as examples the novels of V. Hugo "93 year", L.N. Tolstoy "War and Peace", R. Rollan "The Enchanted Soul", E. Zamyatin "We" and many others. Their role in the development of the philosophical 'picture of the world' is tremendous, because "texts are important primarily as containers that ensure the preservation and dissemination of knowledge." (Gumbrekht, 2016)

However, not only the historical context in many respects determined the features of the philosophical content of literary works, equally important was the national consciousness inherent in the people and their culture. So, for example, in the XIX century, Russian literature and Russian literary criticism became the main forms of philosophical creativity. Novels by L.N. Tolstoy, F.M. Dostoevsky, works of V.G. Belinsky, N.G. Chernyshevsky and many others made it possible to advance quite far in the knowledge of the world, rather than methods of theoretical thinking. Literature was perceived "not to abolish logic, but to fill it with living objectivity; not to violate the fact and the law, but to see the whole thing hidden behind it" (Ilin, 1992, p. 442). West European literature of the XIX century only at the end of the century would come to the philosophical depth as a work of art (T. Mann, G. Mann, O. Wilde, and many others). The XXI century in the context of globalization poses new problems in front of mankind, which can be solved by developing the provisions of the universal "planetary ethics". "By "planetary ethics" we mean those moral attitudes and actions that are characteristic of the very essence of man - his spiritual and moral principle. In other words, the emerging planetary ethics are simple universal human moral standards that need to be disseminated in every possible way everywhere and everywhere" (Nysanbaev, 2017). 
The philosophical content of a literary work largely determines its genre. There is an established opinion that only the scale of a novel or an epic novel can fully reflect the philosophical search for a writer. However, the literature of the XX and XXI centuries significantly diversified the format of philosophical reflection embodied in the literary word. This, for example, the tale of A. de Saint-Exupéry "The Little Prince", the play by B. Brecht "Galileo Galilei", the essay by A. Camus "The Myth of Sisyphus", the story by R. Bach "The Seagull named Jonathan Livingston" and many others.

\section{Findings}

In the stream of modern "minor prose", the stories by the French writer Eric-Emmanuel Schmitt differ in a special manner of speaking about serious philosophical problems. As a doctor of philosophy, he taught for several years before turning to artistic creativity. It seems that deep and serious knowledge allows Schmitt to write about philosophical problems so simply. The writer in his work refuses direct dialogue-appeal, addressed to contemporaries, because, as rightly noted researcher D.V. Panchenko, "it happens that it's smarter not to formulate ideas, but to indirectly point to them, to awaken them in the minds of those to whom they are addressed." (Panchenko, 2018)

\section{Symbols of the work name}

In the work of the writer, named rather symbolically "Children of Noah" (2005), many philosophical problems intertwine that humanity has been trying to solve for a long time. The title refers the reader to the biblical legend of the son of Lamech, who, at the behest of God, made the ark to preserve and continue life on earth after the Flood. However, E. Schmitt fills the famous legend with a different content, significantly expanding the scope of the biblical plot. His Noah is the priest Father Pons, who saved hundreds of Jewish children who were threatened with death in the ghetto during World War II. The Yellow Villa - the place where Father Pons's parish school was located - becomes like a Noah's ark, where those who needed to survive through a difficult time took refuge. Moreover, the priest compares himself with Noah, the biblical character, "the first collector in human history" who "saved all of God's creations". Father Pons seeks to preserve persecuted religions, cultural values rejected by cult personalities during a certain historical period of mankind's existence, and in general he becomes a "collector" of goodness, humanism, selflessness, love. "And you take Noah as an example?" asked little Joseph. "Yes, and like him I collect ... And now I have two collections: gypsies and Jewish. In general, everybody whom Hitler wants to destroy" (Shmitt, 2017, p. 158).

Interestingly enough, the character of the book has a real prototype, about him the writer speaks in dedication: "In memory of Abbot Andre, vicar of St. John the Baptist in Namur parish, as well as all the Righteous of the World" (Shmitt, 2017, p.108). This dedication leads to dramatic pages in the history of the Holocaust. Abbot Andre was one of the activists for the underground movement within the territory of occupied Belgium, thanks to whom many Jewish children were saved.

\section{The image of the protagonist in the context of the philosophical problems of the work}

E. Schmitt, as if pushing off from a historical fact, creates a deeply philosophical work that addresses humanity as a whole. In the artistic interpretation of the real plot, the writer comes up with a very important device: the child becomes the narrator. This is the six-year- 
old Joseph Bernstein, who suffered separation from parents, tests of fear of death, early adulthood in war. Following the biblical wisdom that says "The mouth speaks the truth", Schmitt on behalf of Joseph asks complex philosophical questions that adults cannot answer unambiguously. Trying to understand why his mother was forced to part with him, Joseph, in his own way, seeks an answer from the Countess de Sully, who hid the boy in her house due to the arrests of Jews.

- Are you Jewish too?

- No. I am Belgian.

- I am also a Belgian!

- Yes, you too. But I am a Christian.

- Are Christians against the Jews?

- The Nazis are against the Jews.

- But don't they arrest Christians?

- No.

- So is it better to be a Christian? (Shmitt, 2017, p. 115)

The little character seeks to understand the essence of events that drastically changed his life. And then the author poses questions to which Joseph with his inherent childish maximalism requires clear answers, and adults who are guided by "double standards" cannot give them. Why is the Belgian Joseph Bernstein not protecting his state? By what principle are the parents of a boy who did not even attend the synagogue persecuted and died? Father Pons is trying to explain this, although he does it very conditionally: "He looked at me kindly".

- You are a Jew, Joseph, and even if you prefer my religion, you will still remain a Jew.

- And what does it mean to be Jewish?

- To be chosen. To come from a people that God chose thousands and thousands of years ago.

- Why did he choose us? Because we were better than others? Or, on the contrary, worse?

- Neither one nor the other. You did not have any special advantages or special disadvantages. It just fell to you, that's all.

- But what did it happen to us?

- Mission. Debt. To testify before people that there is only one God and with the help of this God to encourage people to respect themselves and others.

- In my opinion, this did not work out very well, right?

Father Pons did not answer, and I continued:

- If we were chosen, then, rather as a target. After all Hitler wants to destroy us.

- Maybe that's why. Because you are an obstacle to his barbarism. An unusual mission that God has entrusted to your people, and not your people themselves ... (Shmitt, 2017, p. 145).

These difficult questions, to which the boy never received clear answers, make Joseph think hard about them, thinking a lot on his own. Gradually, he turns into a little sage, and his understanding of the world becomes for the writer a kind of life values measure, the starting point of the being concept created in the work. So, an important moment of the personality development for a little hero is the scene when he is forced to attend the mass. At first, he was concerned about the fact that he was not in the synagogue, but in the Catholic Church, but gradually fear gave way to some kind of higher understanding of God. "Having quickly looked around the room, I was convinced that there were enough benches for all of us. But where does God sit? ... Where does God live in this house? ... In the blink of an eye, I understood: God was here. All around us. Everywhere behind us. It was $\mathrm{He}$ the air that trembled sang, soared upward, under the arches, and bent under the dome. It was $\mathrm{He}$ - the air, stained with stained-glass windows, radiant, gentle, smelling of myrrh, 
wax and incense" (Shmitt, 2017, p.142). Intuitively, Joseph realized that God is one, that faith cannot separate people, be the cause of enmity. It is no accident that, looking at a postcard with the image of the Virgin Mary, he thinks about his mother.

\section{The system of images that embodied the main author's intention}

However, questions of nationality and religion as the story unfolds, recede into the background. E. Schmitt as if projects his vision of being on the modern world, in which, unfortunately, nationality and religion are increasingly becoming the cause of large-scale conflicts with a tragic outcome. The author deliberately does not focus on these issues. What becomes more important is what kind of people faced little Joseph on the way to his salvation. Each of these characters makes his moral choice not only in a specific life situation, but also in the "Schmitt" concept of being as a whole. In this gallery of images appears Thick Tjak - "a Jewish traitor who drives around the city in a Gestapo car, and as soon as he spots a Jew on the street, he points to the Germans and they arrest him," and next to him the Bronyarov family, who exhibited a portrait of Hitler in a window of a dairy shop, and the burgomaster Van der Mersch, who during the fascist occupation was concerned only with his own well-being. They are countered by Countess de Sully and her husband, who are bravely trying to resist Nazism by providing asylum in their home for such as Joseph and his parents; pharmacist Mademoiselle Marcel, who claims that she does not like priests, Jews, Germans, but "cannot allow children to be touched," and therefore makes false documents for the wards of Father Pons; a German officer who unexpectedly appeared at the Yellow Villa and clearly understood who the priest was hiding here, but who did not betray him. These heroes are guided by higher humanistic ideals that are not subject to any transient political ideas. There are more of them in the work of E. Schmitt, since according to the author's concept of being, they and like are the pillars of the universe. This is a manifestation of writer's optimism. In his view of the world, in his concept of being, human occupies a special place as the main creative force. It is a human, according to E. Schmitt, who must decide his fate, build a world around him, not hoping for God's help. Even Father Pons is convinced of this, severely chastising Joseph for his thoughts on the possibility of a "deal" with God: "The most dangerous stupidity! People themselves do harm to each other, and God has nothing to do with it. He made people free. This means that we rejoice or suffer regardless of our strengths or weaknesses. What a terrible role you want to give to God! Can you really just for a moment assume that those who managed to escape from the Nazis, God loves, and those who failed, - hates? No, God does not interfere in our affairs! "(Shmitt, 2017, p.172). These words significantly affect the reader's perception of the priest image. The scale of his personality changes significantly: this is not just a provincial servant of the church, but a person for whom faith in God has become a pillar in upholding the most important principles of human existence. As the ancient philosophers said, "the divine nature of human must be grown in the same way as good grapes'. In the work, "Children of Noah," this work is performed by Father Pons, who is more likely to be a philosopher than a priest. It is he who actualizes for the modern reader the philosophical problems of a literary work about World War II. As a true sage, he chose for himself the purpose of life to serve people. And it perpetuated his name. In recognition of his high feat in Israel, a grove of two hundred and seventy trees was planted that symbolized Jewish children rescued by the priest. Over time, young shoots increased the number of trees, but from this their symbolic washing away became even more significant. The matured inhabitants of the Yellow Villa understand this correctly: "... Everything is correct, Joseph. How many children do you have? Four. And grandchildren? Five. In saving you, Father Pons has already saved nine people. And in my case, twelve. The next 
generation will do even more. And further - more and more. In a few centuries, it turns out that he saved millions of people" (Shmitt, 2017, p.207).

\section{Research Method}

The analysis of a literary work allows us to understand and evaluate its ideological potential from a different point of view, aimed at updating the most important philosophical problems of life. This approach to the literary text is implemented using the typological and structurally integrated methods of analysis. The typological method allows us to identify the philosophical component of the ideological and thematic level in the work. The structurally integrated method provides access to the author's concept through the figurative system of the work, the speech characteristics of the heroes, etc. The indicated methods made it possible to more clearly identify the philosophical meaning of the work by E. Schmitt, "Children of Noah."

\section{Conclusion}

As you can see, the idea of the divine origin of the world by Schmitt is not rejected, but for everything that happens in the world and society, the writer believes, the person is responsible. The challenges that humanity is facing today require understanding and searching for solutions to such problems as unity for the sake of saving thousands of lives and cultural values that are perishing in conditions of religious conflicts; awareness of the need for harmony between nature and human; understanding and acceptance of the fact that all nations are self-valuable and equal, and many others. The priest and the child make up a kind of tandem in the work: one cognizes the world with the help of philosophical questions, the other suggests the direction of the search for answers. The reader is also looking for answers, because "the text printed in black and white is unchanged, but at the same time it can serve any reader as a kind of mirror. Like the hero, the reader is put to the test, finds himself in an experimental situation, except that he is weakly or not immediately aware of this" (Venediktova, 2019). Essentially little Joseph with the help of a priest is building his world, his being. All his questions addressed to the senior mentor come down to those that form the basis of any person's worldview: who am I? what's going on around me? where and how did it all come from? what power drives the world? what is the purpose and meaning of world development? In his turn, Father Pons answers to an important philosophical question: why to live? As F.M. Dostoevsky wrote, "the secret of human existence is not only to live, but to what to live for." (Dostoevskij, 2002, p. 545)

Thus, E. Schmitt, continuing the traditions laid down by his outstanding literary predecessors, in his work "Children of Noah" draws on traditional life values and creates the concept of being, according to which the problems of religion and nation should not play a special role in the modern world, but humanity should strive for the harmony of coexistence by all means available to him.

\section{References}

1. Aristotel', $\mathrm{Ob}$ iskusstve poezii (Gos. Izd-vo hudozhestvennoj literatury, Moscow, 1957).

2. V.G. Belinskij, Poln. sobr. soch. (Izd-vo akademii nauk SSSR, Moscow, 1959).

3. T. Venediktova, Literaturnyj diskurs kak teoriya social'nogo, Novoe literaturnoe obozrenie, 1, 2019. 
4. H.U. Gumbrekht, Filologiya i slozhnoe nastoyashchee (per. s angl. N. Poselyagina), Novoe literaturnoe obozrenie, 2, 2016.

5. F.M. Dostoevskij, Brat'ya Karamazovy (Drofa: Veche, Moscow, 2002).

6. I.A. Il'in, O russkoj idee, Il'in I.A. Russkaya ideya (Respublika, Moscow, 1992).

7. A.N. Nysanbaev, Stanovlenie global'noe etiki vzaimoponimaniya, Voprosy filosofii, 8, 2017.

8. D.V. Panchenko, Vojna, filosofiya, intertekstual'nost': Ob odnoj vneshne neznachitel'noj fraze iz rannego Platona, Novoe literaturnoe obozrenie, 5, 2018.

9. E.-E. Shmitt, Deti Noya, Shmitt Oskar i Rozovaya Dama: povesti (AZBUKA, SPb., Azbuka-Attikus, 2017). 